\title{
Effect of 5\% Calcium Hypochlorite on Mechanical Properties of Root Dentin: An in vitro Study
}

\author{
${ }^{1}$ Poornima Reddy, ${ }^{2}$ Suma Balla, ${ }^{3}$ Sandhya S Raghu, ${ }^{4}$ Natanasabapathy Velmurugan \\ ${ }^{5}$ Garlapati T Gupta, ${ }^{6}$ Hrudi S Sahoo
}

\begin{abstract}
Introduction: The aim of this study was to compare in vitro the effect of $5 \%$ calcium hypochlorite $\left[\mathrm{Ca}(\mathrm{OCl})_{2}\right]$ and $5 \%$ sodium hypochlorite $(\mathrm{NaOCl})$ on flexural strength and modulus of elasticity of root dentin.

Materials and methods: The available chlorine concentration of each solution was determined using iodometric titration. Standardized planoparallel dentin bars $(n=20)$ were divided into two test groups and one control group. The control, group 1 , consisted of dentin bars stored in normal saline. The dentin bars in the two test groups were treated by exposure to following solutions: Group 2 to $5 \% \mathrm{Ca}(\mathrm{OCl})_{2}$; and group 3 to $5 \% \mathrm{NaOCl}$. All the three test solutions were changed once in 15 minutes for 30 minutes. The dentin bars were then loaded to failure using three-point bend test.
\end{abstract}

Results: Available chlorine concentration was $64 \%$ in both the test solutions. There was a significant reduction in the flexural strength of $5 \% \mathrm{NaOCl}$ group compared to $5 \% \mathrm{Ca}(\mathrm{OCl})_{2}$-treated ones. A significant difference in modulus of elasticity was observed between the test groups and the control groups and also between the $5 \% \mathrm{Ca}(\mathrm{OCl})_{2}$ and $5 \% \mathrm{NaOCl}$ groups.

Conclusion: Within the limitations of this study, $5 \% \mathrm{NaOC}$ reduced the flexural strength and modulus of elasticity of root dentin bars more when compared to $5 \% \mathrm{Ca}(\mathrm{OCl})_{2}$.

Keywords: Calcium hypochlorite, Elastic modulus, Endodontic irrigant, Flexural strength, Root dentin, Sodium hypochlorite.

How to cite this article: Reddy P, Balla S, Raghu SS, Velmurugan N, Gupta GT, Sahoo HS. Effect of $5 \%$ Calcium Hypochlorite on Mechanical Properties of Root Dentin: An in vitro Study. J Oper Dent Endod 2016;1(2):56-59.

Source of support: Nil

Conflict of interest: None

\section{INTRODUCTION}

Endodontic irrigation plays an important role for the success of root canal treatment. During chemomechanical preparation, the flushing mechanism of the irrigant helps

1,5,6 Student, ${ }^{2}$ Professor, ${ }^{3}$ Senior Lecturer, ${ }^{4}$ Professor and Head

${ }^{1-6}$ Department of Conservative Dentistry and Endodontics Meenkashi Ammal Dental College and Hospital, Chennai, Tamil Nadu, India

Corresponding Author: Poornima Reddy, Student, Department of Conservative Dentistry and Endodontics, Meenkashi Ammal Dental College and Hospital, Chennai, Tamil Nadu, India, Phone: +914423782566, e-mail: drpoornimareddy1988@gmail.com in removal of debris, tissue remnants, and dentin chips from the canal. Recent studies have shown that following mechanical instrumentation, approximately 35 to $50 \%$ of the root canal space still remains uninstrumented. ${ }^{1}$ Hence, the use of an endodontic irrigant during instrumentation is important in order to clean all the areas of the root canal system, particularly those that are inaccessible to instrumentation. $^{2}$

Due to its antimicrobial and tissue dissolution properties, sodium hypochlorite $(\mathrm{NaOCl})$ continues to be one of the most commonly used irrigants in endodontics. Sodium hypochlorite acts through the mechanism of proteolysis and tissue dissolution. ${ }^{3}$ But inadvertent periapical extrusion of this irrigant is known to cause tissue irritation, pain, and swelling. ${ }^{4}$ Studies have shown that $\mathrm{NaOCl}$, when used as an endodontic irrigant, adversely affects the mechanical properties of dentin, namely, flexural strength and modulus of elasticity, thereby compromising the bond strength of adhesive restorations ${ }^{5-10}$ Hence, an alternate irrigant solution, which can overcome these short comings and exhibit tissue dissolution properties comparable to that of $\mathrm{NaOCl}$, may be desirable.

Calcium hypochlorite $\left[\mathrm{Ca}(\mathrm{OCl})_{2}\right]$ is commonly used in water purification $(35 \%)$ and sterilization procedures. ${ }^{11}$ When compared to $\mathrm{NaOCl}$, it has a relatively stable $\mathrm{pH}$ and greater available chlorine (up to $65 \%$ ). Dutta and Saunders ${ }^{12}$ have hypothesized that an accidental periapical extrusion of $\mathrm{Ca}(\mathrm{OCl})_{2}$ may cause less tissue irritation. In a recent study, De Almeida et a ${ }^{13}$ have reported that passive ultrasonic irrigation with $\mathrm{Ca}(\mathrm{OCl})_{2}$ can result in reduction of microbial content within root canal, but it was not statistically significant when compared to passive ultrasonic irrigation with $\mathrm{NaOCl}$. An endodontic irrigant that effectively disinfects the root canal system without altering the properties of the involved tissues may be desirable. Till date there are no studies evaluating the effect of $5 \% \mathrm{Ca}(\mathrm{OCl})_{2}$ when used as an endodontic irrigant on the mechanical properties of root dentin.

Hence, the aim of this study was to evaluate the effect of $5 \% \mathrm{Ca}(\mathrm{OCl})_{2}$ and $5 \% \mathrm{NaOCl}$ solutions on the flexural strength and modulus of elasticity of root dentin. The null hypothesis was that both $\mathrm{Ca}(\mathrm{OCl})_{2}$ and $\mathrm{NaOCl}$ could affect the mechanical properties of root dentin to the same extent. 


\section{MATERIALS AND METHODS}

The flexural properties of materials can be determined by the use of a three-point bend test. ${ }^{14}$

Sixty intact, caries-free permanent human maxillary central incisor teeth were used in this study. Collection, storage, sterilization, and handling of these extracted teeth followed the Occupation Safety and Health Administration guidelines (OSHA, University of California, San Diego, CA, USA). Teeth were sectioned into standardized plano-parallel dentin bars $(1 \times 1 \times \geq 11.7 \mathrm{~mm})$ using a microtome.

The study groups included the control group 1 consisting of dentin bars stored in normal saline, and groups 2 and 3 consisting of dentin bars stored in $5 \% \mathrm{Ca}(\mathrm{OCl})_{2}$ and $5 \% \mathrm{NaOCl}$ solutions respectively.

About $5 \% \mathrm{NaOCl}$ solution (Dentsply, Chennai, India) was used in our study, and $5 \% \mathrm{Ca}(\mathrm{OCl})_{2}$ solution was prepared by diluting a $6 \% \mathrm{Ca}(\mathrm{OCl})_{2}$ solution (Jain Pharmaceuticals \& Chemicals, Chennai, India) by titration method. The available chlorine concentration of the solutions was checked by iodometric titration. The dentin bars were soaked in $50 \mathrm{~mL}$ of the respective solutions in a beaker that was constantly agitated using magnetic stirrer bath (120 agitations/minutes). The solutions were changed every 15 minutes. The total immersion time was 30 minutes.

Three-point bend testing of dentin bars (Central Institute of Plastic Engineering and Technology, Chennai, India) with each bar placed across the lower supports of the test jig and loaded at the mid-point through the loading head was carried out. All the dentin bars were kept moist during testing with distilled water. The loadtesting machine was run at a cross-head speed of $0.5 \mathrm{~mm}$ minutes $^{-1}$ to failure. Data were recorded on a plotter to give load-displacement curves on graph paper. The load at fracture was recorded directly from the load-testing machine and verified against the load-displacement curve.

\section{CALCULATION OF MODULUS OF ELASTICITY AND FLEXURAL STRENGTH}

\section{Modulus of Elasticity}

The slope of the tangent to initial straight line portion of load-deflection curve was drawn, and modulus of elasticity was calculated as

$\mathrm{E}=\left(\mathrm{L}^{3} \mathrm{~m}\right) /\left(4 \mathrm{bd}^{3}\right)$.

\section{Flexural Strength}

The flexural bend strength (FBS) was calculated using the following equation:

$\mathrm{FBS}=(3 \mathrm{P} \mathrm{L}) /\left(2 \mathrm{bd}^{2}\right)$,

where

$\mathrm{E}=$ modulus of elasticity in bending $\left(\mathrm{Nm}^{-2}\right)$
$\mathrm{S}=$ stress at fracture (flexural strength $\mathrm{Nm}^{-2}$ )

$\mathrm{P}=$ load at the moment of fracture $(\mathrm{N})$

$\mathrm{L}=$ the support span $(\mathrm{m})$

$\mathrm{b}=$ the width of beam tested $(\mathrm{m})$

$\mathrm{d}=$ the depth of beam tested $(\mathrm{m})$

$\mathrm{m}=$ the slope of the initial straight-line portion of the load-deflection curve $\left(\mathrm{Nm}^{-1}\right.$ of deflection) (American Society for Testing and Materials, 1989).

\section{Statistical Analysis}

The raw data were tabulated and the means and standard deviation calculated for each group. To compare the mean values between groups, one-way ANOVA was used followed by Tukey's HSD (honest significant difference) test for multiple pairwise comparison.

\section{RESULTS}

\section{Flexural Strength $\left(\mathrm{Nm}^{-2}\right)$}

The means and standard deviations of the flexural strength calculated from the raw data are presented in Table 1. Statistical analysis showed a highly significant ( $p<0.001)$ reduction in the flexural strength values of the $5 \% \mathrm{NaOCl}$ and $\mathrm{Ca}(\mathrm{OCl})_{2}$ groups as compared to the controls. Also, there was highly significant reduction in flexural strength of the $\mathrm{NaOCl}$-treated dentin bars $(\mathrm{p}<0.001)$ than the $\mathrm{Ca}(\mathrm{OCl})_{2}$-treated ones $(\mathrm{p}<0.001)$.

\section{Modulus of Elasticity $\left(\mathrm{Nm}^{-2}\right)$}

The means and standard deviations of the modulus of elasticity calculated from the raw data are presented in Table 2. Analysis showed that there was a highly significant $(p<0.001)$ reduction in the modulus of elasticity of the specimens treated with $5 \% \mathrm{NaOCl}$ as compared to the controls. Also, there was a statistically significant

Table 1: Means and standard deviation of flexural strength of the test groups

\begin{tabular}{|c|c|c|c|}
\hline Groups & Mean $\pm S D$ & $\begin{array}{l}\text { Intergroup } \\
\text { comparison }\end{array}$ & $p$-value \\
\hline \multirow[t]{2}{*}{ Saline } & $69.25 \pm 6.5$ & Saline vs $\mathrm{NaOCl}$ & $<0.001$ \\
\hline & & Saline vs $\mathrm{Ca}(\mathrm{OCl})_{2}$ & $<0.001$ \\
\hline $5 \% \mathrm{Ca}(\mathrm{OCl})_{2}$ & $55.05 \pm 2.8$ & $\mathrm{NaOCl}$ vs $\mathrm{Ca}(\mathrm{OCl})_{2}$ & $<0.001$ \\
\hline $5 \% \mathrm{NaOCl}$ & $49.05 \pm 2.2$ & & \\
\hline
\end{tabular}

Table 2: Means and standard deviation of modulus of elasticity of the test groups

\begin{tabular}{lllr}
\hline Groups & Mean $\pm S D$ & $\begin{array}{l}\text { Intergroup } \\
\text { comparison }\end{array}$ & $p$-value \\
\hline Saline & $0.37 \pm 0.07$ & $\begin{array}{l}\text { Saline vs } \mathrm{NaOCl} \\
\text { Saline vs } \mathrm{Ca}(\mathrm{OCl})_{2}\end{array}$ & $<0.001$ \\
& & 0.035 \\
$5 \% \mathrm{Ca}(\mathrm{OCl})_{2}$ & $0.33 \pm 0.04$ & $\mathrm{NaOCl}$ vs $\mathrm{Ca}(\mathrm{OCl})_{2}$ & 0.035 \\
$5 \% \mathrm{NaOCl}$ & $0.29 \pm 0.02$ & & \\
\hline
\end{tabular}


difference in the modulus of elasticity between the control group and $5 \% \mathrm{Ca}(\mathrm{OCl})_{2}$-treated dentin bars $(\mathrm{p}=0.035)$. The $5 \% \mathrm{NaOCl}$ resulted in a significant reduction in modulus of elasticity when compared to $\mathrm{Ca}(\mathrm{OCl})_{2}$ group $(\mathrm{p}=0.035)$.

\section{DISCUSSION}

Human dentin is made up of $70 \%$ inorganic, $20 \%$ organic content, and $10 \%$ water by volume. ${ }^{15}$ Carbonated apatite is the inorganic component of dentin, whereas the organic phase is predominantly type I collagen fibrils. This composition makes dentin more compliant than enamel, with a typical modulus of elasticity of 11 to $20 \mathrm{GPa} .{ }^{16,17}$ The inorganic phase provides strength, whereas the organic phase is responsible for the toughness of dentin. ${ }^{18}$ Studies have shown that commonly used root canal irrigants can adversely affect the mechanical properties of root dentin. ${ }^{19,20}$

Sodium hypochlorite is most commonly used for pulp tissue dissolution. When used as a root canal irrigant, $\mathrm{NaOCl}$ acts through amino acid neutralization, saponification, and chloramination reactions. At a $\mathrm{pH}$ of $<6.5, \mathrm{NaOCl}$ releases $\mathrm{HOCl}$, thereby contributing to available chlorine content. ${ }^{5}$ Hypochlorite solutions may affect mechanical properties of dentin via the degradation of organic dentin components. ${ }^{21}$ Previous studies have reported that $\mathrm{NaOCl}$ solution causes a concentration-dependent reduction of elastic modulus and flexural strength in human root dentin bars at concentrations of 1,5 , and $9 \%{ }^{22}$

In a previous study by Dutta and Saunders, ${ }^{12}$ iodometric titration was used to determine the concentration of available chlorine content in the $\mathrm{Ca}(\mathrm{OCl})_{2}$ solution. It was found that the available chlorine content of $5 \% \mathrm{Ca}(\mathrm{OCl})_{2}$ solution was comparable to that of $4.65 \% \mathrm{NaOCl}$ (Chlorax) solution. Hence we have used $5 \% \mathrm{Ca}(\mathrm{OCl})_{2}$ in this study.

Protocol suggested by Grigoratos et $\mathrm{al}^{8}$ was followed in this study. Standardized dentin bars were used to study the effect of $\mathrm{NaOCl}$ and $\mathrm{Ca}(\mathrm{OCl})_{2}$ on the mechanical properties of root dentin. Dentin bars were immersed in $50 \mathrm{~mL}$ test solution for 30 minutes, with the solution being changed once in every 15 minutes to simulate clinical situation. Saline was used as control because its properties were similar to that of distilled water. Solutioninduced mechanical alteration was measured applying a three-point bend test. ${ }^{14}$

In $5 \% \mathrm{NaOCl}$-treated groups, the fracture loads were much lower with considerable deformation of the dentin bars prior to fracture. The characteristic bleached and chalky appearance in $\mathrm{NaOCl}$-treated specimens, reported earlier by Sim et al, ${ }^{23}$ was observed in our study.

The flexural strength of $5 \% \mathrm{Ca}(\mathrm{OCl})_{2}$-treated groups was lower when compared to the control group. In $5 \%$
$\mathrm{Ca}(\mathrm{OCl})_{2}$-treated groups, the loads required to fracture were much lower as compared to the controls but higher than those treated with $\mathrm{NaOCl}$ solution. The change in physical properties could be explained by the loss of the organic matrix within the dentin. ${ }^{23}$

A previous study noted that dentin bars treated with $\mathrm{Ca}(\mathrm{OH})_{2}$ and pretreated with $5 \% \mathrm{NaOCl}$ exhibited a drastic decrease in fracture load. They suggested that prior treatment with $\mathrm{NaOCl}$ may have depleted organic portion of dentin to a great extent such that there was no remaining accessible substrate for $\mathrm{Ca}(\mathrm{OH})_{2}$ to act.

There was a decrease in the modulus of elasticity of $5 \% \mathrm{NaOCl}$ group when compared to $5 \% \mathrm{Ca}(\mathrm{OCl})_{2}$ group. Calcium hypochlorite in aqueous solution liberates $\mathrm{Ca}(\mathrm{OH})_{2}$. Wang and Hume ${ }^{24}$ have postulated that $\mathrm{Ca}(\mathrm{OH})_{2}$ does not penetrate dentin well because of buffering capacity of hydroxyapatite. These results are in accordance with a previous study by Dutta and Saunders. ${ }^{12}$ According to them, the presence of $\mathrm{Ca}^{+}$ ions in $\mathrm{Ca}(\mathrm{OCl})_{2}$ could have led to the production of twice as many as hydroxyl ions than in $\mathrm{NaOCl}$ solution. This would have neutralized the $\mathrm{pH}$ and slowed down the rate of formation of $\mathrm{HOCl}$. Hence it may be assumed that $\mathrm{Ca}(\mathrm{OCl})_{2}$ may have more pronounced effect on the superficial surface of the dentin than its interiors. Thus the null hypothesis was rejected. Further studies to evaluate the effect of $\mathrm{Ca}(\mathrm{OCl})_{2}$ on root canal sealer penetration and bond strength should be performed, when used as an endodontic irrigant.

\section{CONCLUSION}

Within the limitations of this study, when used as an irrigant,

- $5 \% \mathrm{NaOCl}$ and $5 \% \mathrm{Ca}(\mathrm{OCl})_{2}$ have significant detrimental effect on flexural strength and modulus of elasticity of root dentin in comparison with normal saline.

- $5 \% \mathrm{NaOCl}$ reduced the flexural strength and modulus of elasticity of root dentin bars more when compared to $5 \% \mathrm{Ca}(\mathrm{OCl})_{2}$.

\section{REFERENCES}

1. Peters OA, Laib A, Göhring TN, Barbakow F. Changes in root canal geometry after preparation assessed by high-resolution computed tomography. J Endod 2001 Jan;27(1):1-6.

2. Zehnder M. Root canal irrigants. J Endod 2006 May;32(5): 389-398.

3. Estrela C, Estrela CR, Barbin EL, Spanó JC, Marchesan MA, Pécora JD. Mechanism of action of sodium hypochlorite. Braz Dent J 2002;13(2):113-117.

4. Bosch-Aranda ML, Canalda-Sahli C, Figueiredo R, GayEscoda C. Complications following an accidental sodium hypochlorite extrusion: a report of two cases. J Clin Exp Dent 2012 Jul 1;4(3):e194-e198. 
5. Goldsmith M, Gulabivala K, Knowles JC. The effect of sodium hypochlorite irrigant concentration on tooth surface strain. J Endod 2002 Aug;28(8):575-579.

6. Zaparolli D, Saquy PC, Cruz-Filho AM. Effect of sodium hypochlorite and EDTA irrigation, individually and in alternation, on dentin microhardness at the furcation area of mandibular molars. Braz Dent J 2012;23(6):654-658.

7. Slutzky-Goldberg I, Maree M, Liberman R, Heling I. Effect of sodium hypochlorite on dentin microhardness. J Endod 2004 Dec;30(12):880-882.

8. Grigoratos D, Knowles J, Ng YL, Gulabivala K. Effect of exposing dentin to sodium hypochlorite and calcium hydroxide on its flexural strength and elastic modulus. Int Endod J 2001 Mar;34(2):113-119.

9. Marshall GW, Yücel N, Balooch M, Kinney JH, Habelitz S, Marshall SJ. Sodium hypochlorite alterations of dentin and dentin collagen. Surf Sci 2001 Oct;491(3):444-455.

10. Farina AP, Cecchin D, Barbizam JV, Carlini-Júnior B. Influence of endodontic irrigants on bond strength of a self-etching adhesive. Aust Endod J 2011 Apr;37(1):26-30.

11. Whittaker HA, Mohler BM. The sterilization of milk bottles with calcium hypochlorite. Am J Public Health (NY) 1912 Apr;2(4):282-287.

12. Dutta A, Saunders WP. Comparative evaluation of calcium hypochlorite and sodium hypochlorite on soft-tissue dissolution. J Endod 2012 Oct;38(10):1395-1398.

13. DeAlmeida AP,Souza MA, MiyagakiDC, Dal Bello Y,CecchinD, Farina AP. Comparative evaluation of calcium hypochlorite and sodium hypochlorite associated with passive ultrasonic irrigation on antimicrobial activity of a root canal system infected with Enterococcus faecalis: an in vitro study. J Endod 2014 Dec;40(12):1953-1957.

14. American Society for Testing and Materials D790M. Standard test methods for flexural properties of un-reinforced and reinforced plastics and electrical insulating materials. In:
Annual book of ASTM standards. Vol. 08.01. Philadelphia (PA): American Society for Testing and Materials; 1989. p. 290-298.

15. Avery JK. Pulp. In: Bhaskar SN, editor. Orban's oral histology and embrology. 11th ed. Chicago (IL): Mosby; 1990. p. 110.

16. Kinney JH, Marshall SJ, Marshall GW. The mechanical properties of human dentin: a critical review and re-evaluation of the dental literature. Crit Rev Oral Biol Med 2003;14(1):13-29.

17. Kinney JH, Pople JA, Marshall GW, Marshall SJ. Collagen orientation and crystallite size in human dentin: a small angle X-ray scattering study. Calcif Tissue Int 2001 Jul;69(1):31-37.

18. Dubey DK, Tomar V. Role of molecular level interfacial forces in hard biomaterial mechanics: a review. Ann Biomed Eng 2010 Jun;38(6):2040-2055.

19. Machnick TK, Torabinejad M, Munoz CA, Shabahang S. Effect of MTAD on flexural strength and modulus of elasticity of dentin. J Endod 2003 Nov;29(11):747-750.

20. Marending M, Paqué F, Fischer J, Zehnder M. Impact of irrigant sequence on mechanical properties of human root dentin. J Endod 2007 Nov;33(11):1325-1328.

21. Zhang K, Kim YK, Cadenaro M, Bryan TE, Sidow SJ, Loushine RJ, Ling JQ, Pashley DH, Tay FR. Effects of different exposure times and concentrations of sodium hypochlorite/ethylenediaminetetraacetic acid on the structural integrity of mineralized dentin. J Endod 2010 Jan;36(1):105-109.

22. Marending M, Luder HU, Brunner TJ, Knecht S, Stark WJ, Zehnder M. Effect of sodium hypochlorite on human root dentin-mechanical, chemical and structural evaluation. Int Endod J 2007 Oct;40(10):786-793.

23. Sim TP, Knowles JC, Ng YL, Shelton J, Gulabivala K. Effect of sodium hypochlorite on mechanical properties of dentin and tooth surface strain. Int Endod J 2001 Mar;34(2):120-132.

24. Wang JD, Hume WR. Diffusion of hydrogen ion and hydroxyl ion from various sources through dentin. Int Endod J 1988 Jan;21(1):17-26. 